\title{
No evidence for the involvement of the argasid tick Ornithodoros faini in the enzootic maintenance of marburgvirus within Egyptian rousette bats Rousettus aegyptiacus
}

\author{
Amy J. Schuh', Brian R. Amman', Dmitry A. Apanaskevich², Tara K. Sealy', Stuart T. Nichol ${ }^{1}$ \\ and Jonathan S. Towner ${ }^{1 *}$
}

\begin{abstract}
Background: The cave-dwelling Egyptian rousette bat (ERB; Rousettus aegyptiacus) was recently identified as a natural reservoir host of marburgviruses. However, the mechanisms of transmission for the enzootic maintenance of marburgviruses within ERBs are unclear. Previous ecological investigations of large ERB colonies inhabiting Python Cave and Kitaka Mine, Uganda revealed that argasid ticks (Ornithodoros faini) are hematophagous ectoparasites of ERBs. Yet, their potential role as transmission vectors for marburgvirus has not been sufficiently assessed.

Findings: In the present study, 3,125 O. faini were collected during April 2013 from the rock crevices of Python Cave, Uganda. None of the ticks tested positive for marburgvirus-specific RNA by Q-RT-PCR. The probability of failure to detect marburgvirus at a conservative prevalence of $0.1 \%$ was 0.05 .
\end{abstract}

Conclusions: The absence of marburgvirus RNA in $O$. faini suggests they do not play a significant role in the transmission and enzootic maintenance of marburgvirus within their natural reservoir host.

Keywords: Filovirus, Marburgvirus, Marburg virus, Tick, Argasid, Ornithodoros, Egyptian rousette bat, Rousettus aegyptiacus, Transmission, Maintenance

\section{Findings Introduction}

The genus Marburgvirus (Filoviridae), includes a single species, Marburg marburgvirus, with two virus members, Marburg virus (MARV) and Ravn virus (RAVV) (hereafter collectively referred to as marburgvirus). These viruses cause outbreaks of hemorrhagic disease perpetuated by human-to-human transmission, with reported case fatality ratios up to $90 \%$. Ecological investigations have identified the cave-dwelling Egyptian rousette bat (ERB; Rousettus aegyptiacus) as a natural reservoir host for marburgvirus $[1,2]$, based upon the detection of marburgvirus RNA and

\footnotetext{
* Correspondence: jit8@cdc.gov

'Viral Special Pathogens Branch, Division of High-Consequence Pathogens and Pathology, Centers for Disease Control and Prevention, Atlanta, GA, USA

Full list of author information is available at the end of the article
}

IgG antibodies $[3,4]$ and the isolation of infectious marburgvirus [1-3,5] from ERBs inhabiting caves associated with recent human outbreaks. Experimental infection of captive ERBs with MARV has confirmed their natural reservoir host status by demonstrating MARV replication in a range of tissues [6-8] and oral shedding of infectious virus in the absence of clinical disease $[7,8]$ followed by seroconversion [6-8]. Although it has been hypothesized that MARV is transmitted between ERBs by direct contact with infectious MARV oral secretions through activities such as touching, licking and biting [7], a recent study was unable to show horizontal transmission within a 42 day period from MARV-experimentally infected ERBs to susceptible in-contact ERBs [9]. It has been suggested that enzootic transmission and maintenance of marburgvirus 
within the ERB population may involve an intermediate host, such as an arthropod vector [1, 7-9].

Argasid ticks (Ornithodoros faini; $=$ Carios faini, Alectorobius faini) have been observed on the bodies of ERBs inhabiting a cave in Kruger National Park, South Africa [10] and previous ecological investigations of large ERB colonies inhabiting Python Cave and Kitaka Mine, Uganda revealed that $O$. faini are hematophagous ectoparasites of ERBs [1, 2]. Ornithodoros spp. ticks are known vectors of several arboviruses including African swine fever [11], bluetongue [12], Karshi [13], Langat $[13,14]$ and Qalyub [15] viruses. A previous collection of approximately 300 adult and nymphal argasid ticks taken from rock crevices near ERB roosting sites at Python Cave and Kitaka Mine were negative for marburgvirus RNA by Q-RT-PCR [1, 2]. However, given the limited sample size, further collection and testing of these arthropods was considered important to determine whether they play a role in the enzootic transmission and maintenance of marburgvirus.

\section{Methods}

A total of 3,125 adult and nymph argasid ticks were individually collected using forceps from small rock crevices near bat roosting sites within Python Cave, Queen Elizabeth National Park, Uganda in April 2013. The tick collections were undertaken with the approval of the Uganda Wildlife Authority and performed in accordance with a protocol approved by the Centers for Disease Control and Prevention's Institutional Animal Care and Use Committee. The cave is inhabited by a sole chiropteran population consisting of approximately 40,000 ERB individuals with a consistent $2.5 \%$ prevalence of active marburgvirus infection [2]. Between 2007 and 2008, two epidemiologically unrelated cases of Marburg hemorrhagic fever occurred in tourists 7-10 days after visiting Python Cave $[16,17]$.

Pools of five ticks were placed directly in 2-mL grinding vials (OPS Diagnostics, Lebanon, NJ) containing $250 \mu \mathrm{L}$ of a 1:1 ratio of MagMax Lysis Binding Solution (Life Technologies, Grand Island, NY) to isopropanol (MagMax Lysis Binding buffer). The tick pools were homogenized for $2 \mathrm{~min}$ at 1,500 strokes per minute using the GenoGrinder 2000 (OPS Diagnostics, Lebanon, NJ). After the addition of $550 \mu \mathrm{L}$ of MagMax Lysis buffer, the pools were transferred to cryovials and immediately stored under liquid nitrogen vapors. Nucleic acid was extracted using the MagMax Pathogen RNA/DNA Kit (Life Technologies, Grand Island, NY) on the MagMax Express-96 Deep Well Magnetic Particle Processor (Life Technologies, Grand Island, NY). All samples were analyzed by quantitative-reverse transcriptase-polymerase chain reaction (Q-RT-PCR) on the 7500 Real-Time PCR System (Life Technologies, Grand Island, NY) using the
SuperScript III Platinum One-Step Q-RT-PCR Kit (Life Technologies, Grand Island, NY) with marburgvirusspecific primers and probes targeting the viral protein 40 gene [2], as well as with tick-specific primer and probes targeting the mitochondrial $16 \mathrm{~s}$ ribosomal RNA (rRNA) gene (endogenous control to confirm nucleic acid integrity).

A short region ( 450 bp) of the $16 \mathrm{~s}$ rRNA gene of three samples was amplified using the SuperScript III One-Step RT-PCR System with the Platinum Taq High Fidelity DNA Polymerase Kit (Life Technologies, Grand Island, NY) and then sequenced using the Big Dye Terminator v3.1 Cycle Sequencing Kit (Life Technologies, Grand Island, NY) and six primers on the ABI Prism 3100 Genetic Analyzer (Life Technologies, Grand Island, NY). These sequences [GenBank: KU295468KU295470], as well as morphological examination of a set of ticks preserved in $70 \%$ ethanol, were used to confirm the $O$. faini species designation.

\section{Results and discussion}

None of the tick pools (0/625) were positive for marburgvirus-specific RNA, while 95.7 \% (598/625) of the pools were positive for tick-specific 16srRNA ( $4.3 \%$ of the pools were $16 \mathrm{~s}$ rRNA negative indicating the presence of nucleic acid inhibitors in these samples). The probability of failure to detect marburgvirus RNA in this sample size of 2,990 ticks (598 pools of 5) at a conservative prevalence of $0.1 \%$ was 0.05 .

Adult Ornithodoros spp. feed and reproduce repeatedly, [18] and survive up to 20 years [19]. Further, these ticks have been shown to harbor infectious African swine fever virus for more than five years [20], transmit Langat virus more than three years after oral exposure [13] and transmit Karshi virus nearly eight years following oral exposure [21]. The natural history of Ornithodoros spp. suggests that if $O$. faini was a vector for marburgvirus then its presence would have been detected in our tick collection. However, an experimental infection study showed that ERBs inoculated with a large dose of MARV (4 $\log _{10} \mathrm{TCID}_{50}$ ) exhibited relatively low peak viremias $\left(3.3 \log _{10} \mathrm{TCID}_{50}\right.$ genome equivalents $/ \mathrm{mL}$ ) of short duration (3 days) [7]. Furthermore, an ecological investigation revealed that only $5 \%$ of wild-caught ERBs shown to be actively infected with marburgvirus had detectable viremias [2]. Together these data suggest that marburgvirus-infected ERBs may not produce sufficiently high viremias for feeding O. faini to acquire the virus. Similarly, the low viremias would make mechanical transmission unlikely. It is also possible that either the midgut epithelial or salivary gland cells of O. faini are refractory to marburgvirus infection or replication. A previous laboratory study found that Ornithodoros spp. ticks intrathoracically inoculated with Reston virus 
(Family Filoviridae), to bypass the midgut barrier, showed no evidence of virus replication [22].

In conclusion, this study found no evidence for $O$. faini playing a significant role in the enzootic transmission and maintenance of marburgvirus.

\section{Abbreviations}

ERB: Egyptian fruit bat; MARV: Marburg virus; Q-RT-PCR: Quantitative-reverse transcriptase-polymerase chain reaction; rRNA: Ribosomal RNA.

\section{Competing interests}

The findings and conclusions in this report are those of the authors and do not necessarily represent the views of the Centers for Disease Control and Prevention. The authors have no financial, personal, or professional interests that inappropriately influenced this paper.

\section{Authors' contributions}

AJS, BRA and JST designed the study and collected the ticks. AJS and TKS performed experiments. AJS analyzed the data. DAA morphologically identified the ticks. AJS, STN and JST wrote the paper. All authors read and approved the final manuscript.

\section{Acknowledgements}

We would like to thank Dr. Michael Levin and Lauren McColley from the Rickettsial Zoonoses Branch at the Centers for Disease Control and Prevention for donating ticks for the pre-study experimental optimizations, Dr. Margret Driciru and the Uganda Wildlife Authority rangers at Python Cave for their support during this study, and Dr. Cesar Albarino for assistance with DNA sequencing.

\section{Disclaimer}

The findings and conclusions in this report are those of the authors and do not necessarily represent the views of the Centers for Disease Control and Prevention.

\section{Author details}

${ }^{1}$ Viral Special Pathogens Branch, Division of High-Consequence Pathogens and Pathology, Centers for Disease Control and Prevention, Atlanta, GA, USA. ${ }^{2}$ United States National Tick Collection, the James H. Oliver, Jr. Institute for Coastal Plain Science, Georgia Southern University, Statesboro GA, USA.

\section{Received: 11 January 2016 Accepted: 17 February 2016}

Published online: 05 March 2016

\section{References}

1. Towner JS, Amman BR, Sealy TK, Carroll SA, Comer JA, Kemp A, et al. Isolation of genetically diverse Marburg viruses from Egyptian fruit bats. PLoS Pathog. 2009;5(7):e1000536.

2. Amman BR, Carroll SA, Reed ZD, Sealy TK, Balinandi S, Swanepoel R, et al. Seasonal pulses of Marburg virus circulation in juvenile Rousettus aegyptiacus bats coincide with periods of increased risk of human infection. PLoS Pathog. 2012;8(10):e1002877.

3. Swanepoel R, Smit SB, Rollin PE, Formenty P, Leman PA, Kemp A, et al. Studies of reservoir hosts for Marburg virus. Emerg Infect Dis. 2007;13(12):1847-51.

4. Towner JS, Pourrut X, Albarino CG, Nkogue CN, Bird BH, Grard G, et al. Marburg virus infection detected in a common African bat. PLoS One. 2007;2(8):e764.

5. Amman BR, Nyakarahuka L, McElroy AK, Dodd KA, Sealy TK, Schuh AJ, et al. Marburgvirus resurgence in Kitaka Mine bat population after extermination attempts, Uganda. Emerg Infect Dis. 2014;20(10):1761-4.

6. Paweska JT, Jansen van Vuren P, Masumu J, Leman PA, Grobbelaar AA, Birkhead $M$, et al. Virological and serological findings in Rousettus aegyptiacus experimentally inoculated with vero cells-adapted hogan strain of Marburg virus. PLoS One. 2012;7(9):e45479.

7. Amman BR, Jones ME, Sealy TK, Uebelhoer LS, Schuh AJ, Bird BH, et al. Oral shedding of marburg virus in experimentally infected Egyptian fruit bats (Rousettus aegyptiacus). J Wildl Dis. 2015;51(1):113-24.

8. Jones ME, Schuh AJ, Amman BR, Sealy TK, Zaki SR, Nichol ST, et al. Experimental inoculation of Egyptian rousette bats (rousettus aegyptiacus) with viruses of the ebolavirus and marburgvirus genera. Viruses. 2015;7(7):3420-42
9. Paweska JT, Jansen van Vuren P, Fenton KA, Graves K, Grobbelaar AA, Moolla N, Leman P, Weyer J, Storm N, McCulloch SD et al. Lack of marburg virus transmission from experimentally infected to susceptible in-contact egyptian fruit bats. J Infect Dis. 2015:212:S109-18.

10. Braack LEO. Arthropod inhabitants of a tropical cave 'island' environment provisioned by bats. Biol Conserv. 1989:48:77-84.

11. Mellor PS, Wilkinson PJ. Experimental transmission of African swine fever virus by Ornithodoros savignyi (Audouin). Res Vet Sci. 1985;39(3):353-6.

12. Stott JL, Osburn BI, Alexander L. Ornithodoros coriaceus (pajaroello tick) as a vector of bluetongue virus. Am J Vet Res. 1985;46(5):1197-9.

13. Turell MJ, Mores CN, Lee JS, Paragas JJ, Shermuhemedova D, Endy TP, et al. Experimental transmission of Karshi and Langat (tick-borne encephalitis virus complex) viruses by Ornithodoros ticks (Acari: Argasidae). J Med Entomol. 2004;41(5):973-7.

14. Turell MJ, Durden LA. Experimental transmission of Langat (tick-borne encephalitis virus complex) virus by the soft tick Ornithodoros sonrai (Acari: Argasidae). J Med Entomol. 1994;31(1):148-51.

15. Miller BR, Loomis R, Dejean A, Hoogstraal H. Experimental studies on the replication and dissemination of Qalyub virus (Bunyaviridae: Nairovirus) in the putative tick vector, Ornithodoros (Pavlovskyella) erraticus. Am J Trop Med Hyg. 1985;34(1):180-7.

16. Timen A, Koopmans MP, Vossen AC, van Doornum GJ, Gunther S, van den Berkmortel F, et al. Response to imported case of Marburg hemorrhagic fever, the Netherland. Emerg Infect Dis. 2009:15(8):1171-5.

17. Centers for Disease C, Prevention. Imported case of Marburg hemorrhagic fever - Colorado. MMWR Morbidity and mortality weekly report 2009. 2008; 58(49):1377-81.

18. Hoogstraal H. Argasid and nuttalliellid ticks as parasites and vectors. Adv Parasitol. 1985:24:135-238.

19. Encinas-Grandes A, Oleaga-Perez A, Perez-Sanchez R, Astingarraga A. Datos sobre el reservorio y vector de la peste porcina Africana, Ornithodoros erraticus. Anaporc. 1993;121:38-47.

20. Boinas FS, Wilson AJ, Hutchings GH, Martins C, Dixon $\amalg$. The persistence of African swine fever virus in field-infected Ornithodoros erraticus during the ASF endemic period in Portugal. PLoS One. 2011:6(5):e20383.

21. Turell MJ. Experimental transmission of karshi (mammalian tick-borne Flavivirus group) virus by ornithodoros ticks $>2,900$ days after initial virus exposure supports the role of soft ticks as a long-term maintenance mechanism for certain flaviviruses. PLoS Negl Trop Dis. 2015:9(8):e0004012.

22. Turell MJ, Bressler DS, Rossi CA. Short report: lack of virus replication in arthropods after intrathoracic inoculation of Ebola Reston virus. Am J Trop Med Hyg. 1996;55(1):89-90.
Submit your next manuscript to BioMed Central and we will help you at every step:

- We accept pre-submission inquiries

- Our selector tool helps you to find the most relevant journal

- We provide round the clock customer support

- Convenient online submission

- Thorough peer review

- Inclusion in PubMed and all major indexing services

- Maximum visibility for your research

Submit your manuscript at www.biomedcentral.com/submit 